\title{
The ovarian stroma as a new frontier
}

\author{
Hadrian M Kinnear ${ }^{1,2}$, Claire E Tomaszewski ${ }^{3}$, Faith L Chang ${ }^{3}$, Molly B Moravek ${ }^{4,5,6}$, Min Xu ${ }^{4,5}$, \\ Vasantha Padmanabhan ${ }^{4,7}$ and Ariella Shikanov $\mathbb{D}^{1,3,4}$ \\ ${ }^{1}$ Program in Cellular and Molecular Biology, University of Michigan, Ann Arbor, Michigan, USA, ${ }^{2}$ Medical Scientist \\ Training Program, University of Michigan, Ann Arbor, Michigan, USA, ${ }^{3}$ Department of Biomedical Engineering, \\ University of Michigan, Ann Arbor, Michigan, USA, ${ }^{4}$ Department of Obstetrics and Gynecology, University of \\ Michigan, Ann Arbor, Michigan, USA, ${ }^{5}$ Division of Reproductive Endocrinology and Infertility, University of \\ Michigan, Ann Arbor, Michigan, USA, ${ }^{6}$ Department of Urology, University of Michigan, Ann Arbor, Michigan, USA \\ and ${ }^{7}$ Department of Pediatrics and Communicable Diseases, University of Michigan, Ann Arbor, Michigan, USA
}

Correspondence should be addressed to A Shikanov; Email: shikanov@umich.edu

\begin{abstract}
Historically, research in ovarian biology has focused on folliculogenesis, but recently the ovarian stroma has become an exciting new frontier for research, holding critical keys to understanding complex ovarian dynamics. Ovarian follicles, which are the functional units of the ovary, comprise the ovarian parenchyma, while the ovarian stroma thus refers to the inverse or the components of the ovary that are not ovarian follicles. The ovarian stroma includes more general components such as immune cells, blood vessels, nerves, and lymphatic vessels, as well as ovary-specific components including ovarian surface epithelium, tunica albuginea, intraovarian rete ovarii, hilar cells, stem cells, and a majority of incompletely characterized stromal cells including the fibroblast-like, spindle-shaped, and interstitial cells. The stroma also includes ovarian extracellular matrix components. This review combines foundational and emerging scholarship regarding the structures and roles of the different components of the ovarian stroma in normal physiology. This is followed by a discussion of key areas for further research regarding the ovarian stroma, including elucidating theca cell origins, understanding stromal cell hormone production and responsiveness, investigating pathological conditions such as polycystic ovary syndrome (PCOS), developing artificial ovary technology, and using technological advances to further delineate the multiple stromal cell types.

Reproduction (2020) 160 R25-R39
\end{abstract}

\section{What is the ovarian stroma and what does it do?}

Organs are comprised of two components: (1) the parenchyma, or the specialized tissue that performs the function of the organ, and (2) the stroma, which is typically the supporting tissue (Young et al. 2014, Mescher 2018). Ovarian follicles, which are the functional units of the ovary, comprise the ovarian parenchyma. Conceptualizing the stroma as the inverse of the parenchyma, the ovarian stroma thus refers to the components of the ovary that are not ovarian follicles. The ovarian stroma is comprised of general components such as immune cells (Wu et al. 2004), blood vessels (Reeves 1971), nerves (Neilson et al. 1970), and lymphatic vessels (Brown et al. 2010), as well as ovaryspecific components. These ovary-specific components include ovarian surface epithelium (Auersperg et al. 2001), tunica albuginea (Reeves 1971), intraovarian rete ovarii (Wenzel \& Odend'hal 1985), hilar cells (Neilson et al. 1970), ovarian stem cells (Hummitzsch et al. 2015), a majority of incompletely characterized stromal cells that includes the fibroblast-like, spindleshaped, and interstitial cells (Reeves 1971), and possibly other cell types not included in this list. In addition to these cell types, ovarian extracellular matrix $(E C M)$ provides structural and biochemical support to surrounding cells and is a key component of the stroma (Berkholtz et al. 2006) (Fig. 1 and Table 1). Some studies have used the broad terms 'ovarian interstitial stroma' or 'theca interstitial cells' (TICs) to refer to the heterogeneous stromal compartment (e.g. Tingen et al. 2011, Hummitzsch et al. 2019). For the purpose of this review, we will interpret the ovarian stroma as the broadly inclusive non-follicular components of the ovary. We also want to highlight that the term 'stromal cells' does not refer to a single homogenous cell population. Instead, when feasible, we recommend more specific descriptions like 'stromal macrophages' to refer to individual components of the stromal compartment. What is known about the multiple cell types and components of the stroma is detailed subsequently. 


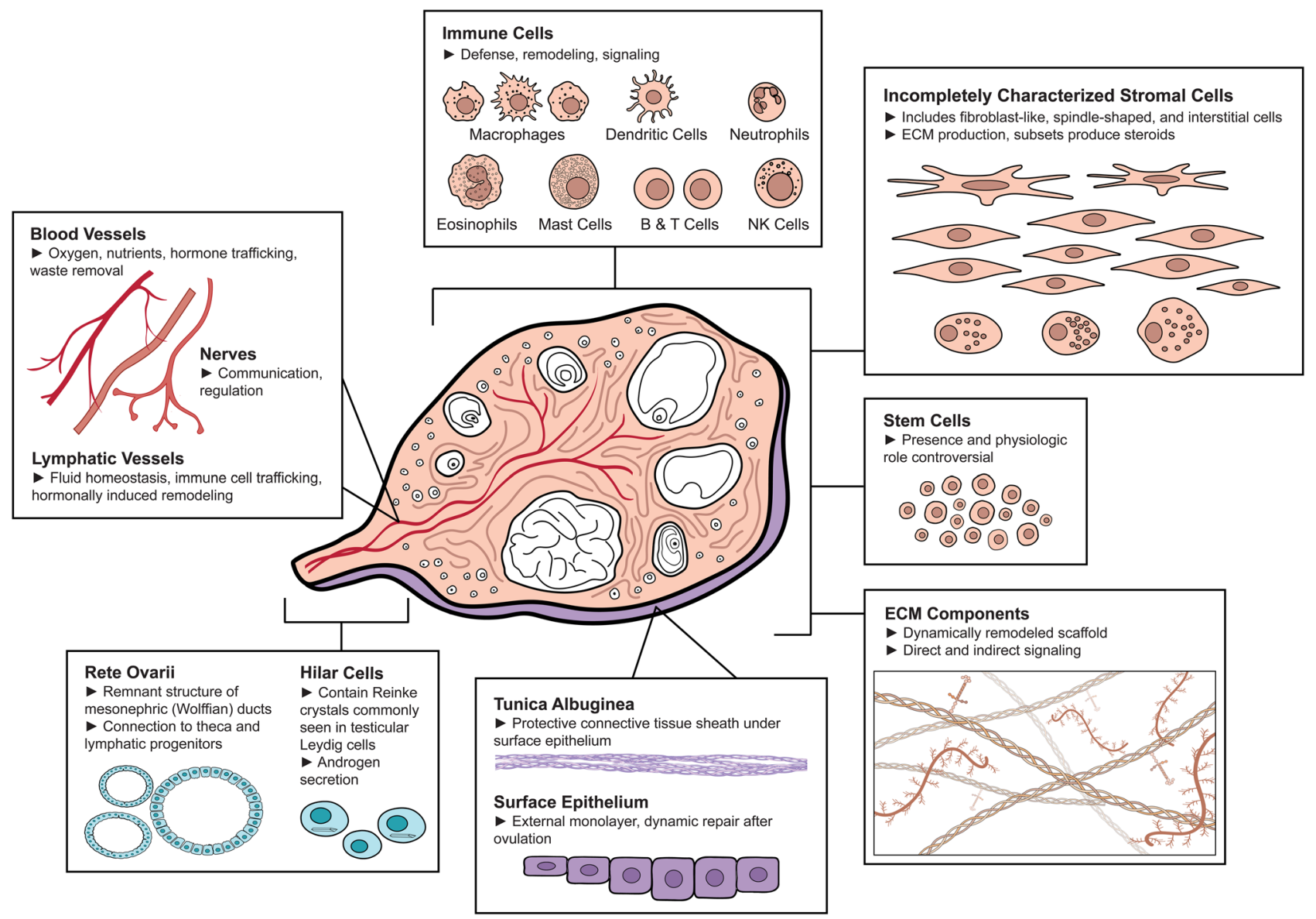

Figure 1 Components of the ovarian stroma. Central diagram of a human ovary (adapted from Gray 1918) surrounded by boxes highlighting different ovarian stromal components including (clockwise from top center): immune cells including macrophages, dendritic cells, neutrophils, eosinophils, mast cells, B \& T cells, and Natural Killer (NK) cells; incompletely characterized stromal cells (including fibroblast-like, spindleshaped, and interstitial cells); stem cells; extracellular matrix (ECM) components; surface epithelium and tunica albuginea; rete ovarii and hilar cells; and blood vessels, lymphatic vessels, and nerves. Made using @BioRender - biorender.com.

\section{General cell types of the ovarian stroma}

Immune cells

Cells of the immune system appear to play critical roles in supporting ovarian physiologic processes. Immune cells, including macrophages, mast cells, and eosinophils, are present in immature or resting ovaries at low levels throughout the stroma. These levels tend to increase around ovulation, particularly near the theca vasculature, with subsequent migration into developing corpora lutea (Norman \& Brannstrom 1994). Ovarian immune cells serve multiple functions, including phagocytosis and antigen presentation, tissue remodeling via proteolytic enzymes, and secretion of soluble signals including cytokines, chemokines, and growth factors (Norman \& Brannstrom 1994, Wu et al. 2004). Macrophages are a predominant ovarian immune cell type, with other immune cells present including B and T lymphocytes, Natural Killer cells, dendritic cells, neutrophils, eosinophils, and mast cells (Norman \& Brannstrom 1994, Suzuki et al. 1998, Carlock et al.
2013, Kenngott et al. 2016, Fan et al. 2019, Zhang et al. 2020) (Fig. 1 and Table 1). Ovarian macrophages have received ongoing attention with regard to their role in reproductive homeostasis and their regulation by estrogen (reviewed in Wu et al. 2004, Pepe et al. 2018). Ovaries may contain multiple macrophage subsets, and phenotypes can range from classical inflammatory (M1) to alternative tissue remodeling (M2) during different parts of the ovarian cycle (Carlock et al. 2013, Pepe et al. 2018). Increased proportions of M2 macrophages, monocyte-derived macrophages, and multinucleated macrophages have been seen with murine ovarian aging (Briley et al. 2016, Zhang et al. 2020). Macrophage and other myeloid cell depletion using the CD11b-DTR mouse model has resulted in infertility, with hemorrhagic ovaries, ovarian endothelial cell depletion, impaired corpora lutea formation, and diminished progesterone production (Turner et al. 2011, Care et al. 2013). Although ovarian immune cells, particularly macrophages, have been the subjects of ongoing research, gaps in knowledge remain regarding 


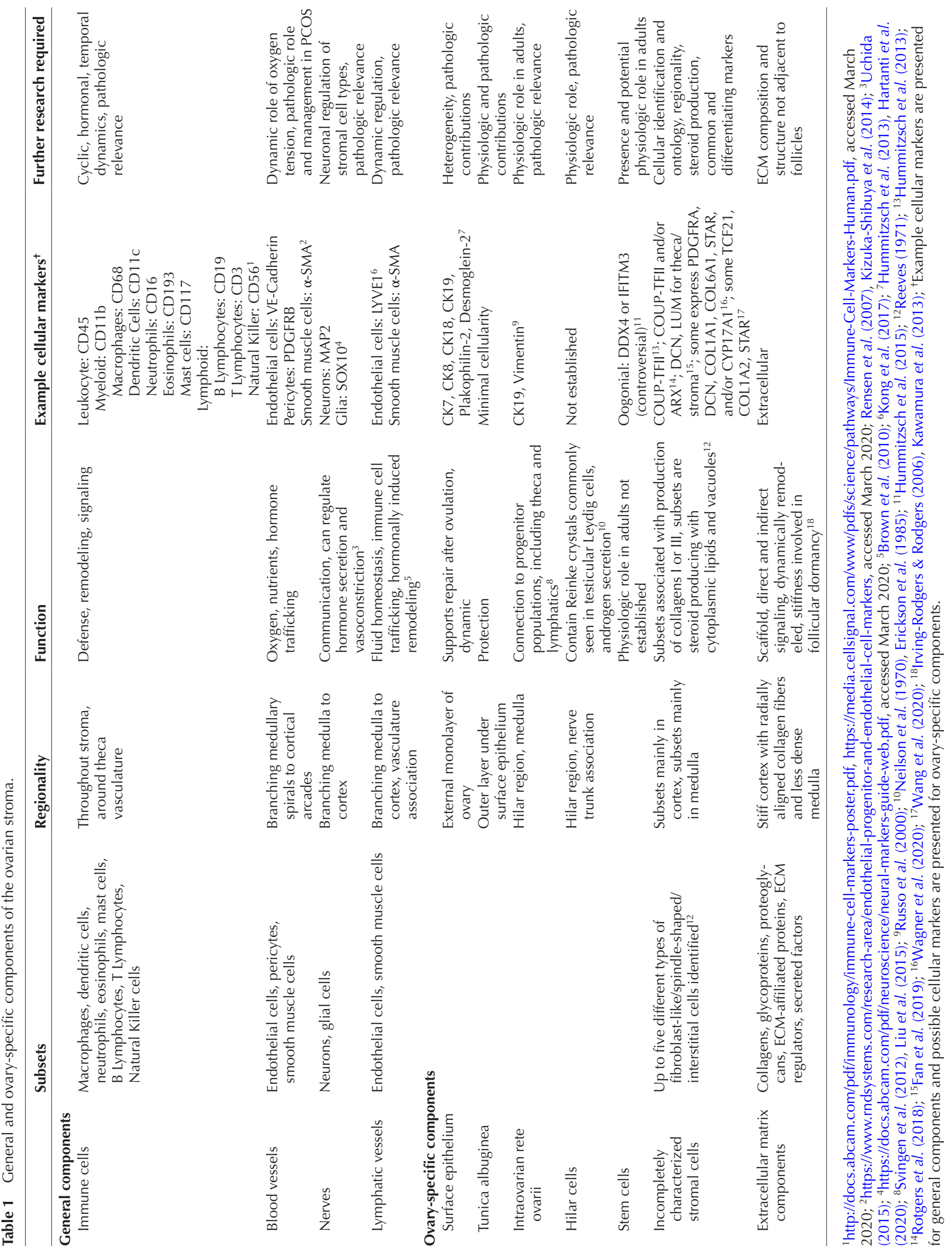


cyclic, hormonal, and temporal dynamics as well as contributions to ovarian pathologic conditions (Table 1).

\section{Blood vessels}

The vasculature of the ovary supports critical ovarian functions and includes blood vessel endothelial cells, pericytes, and smooth muscle cells (Fig. 1 and Table 1). Ovarian blood vessels travel through connective tissue to provide tissue oxygenation, hormone trafficking, and nutrients, in addition to supporting waste removal. The medulla of the human ovary typically contains the larger blood vessels, and at the cortico-medullary junction, small medullary arteries branch to cortical arterioles (Reeves 1971). These cortical arterioles form vascular arcades of interconnected short straight vessels of fixed length running along the connective tissue fascicles. With pressure, the cortical arterioles could be compressed to form avascular regions as part of the formation of stigma for ovulation (Reeves 1971). Medullary vessels include spiraling arteries and arterioles, which may allow expansion with growth (Reeves 1971). The microvasculature of the ovary contributes to folliculogenesis and corpora lutea formation. Follicles contain a basal lamina between their granulosa and theca cell compartments, allowing for a blood-follicle barrier (Siu \& Cheng 2012). With the formation of the theca cell layer, follicles develop microvasculature between the theca cells that supports the increased growth and development of the follicle, yet never passes beyond the basal lamina before ovulation. The formation of the corpus luteum, a highly vascular structure, occurs after theca microvasculature invades into the granulosa layer following ovulation (Rolaki et al. 2005). Gaps in knowledge remain around the role of oxygen tension, as regulated by ovarian vasculature. Oxygen tension may have regulatory effects in the ovary, with in vitro studies demonstrating that oxygen levels can impact bovine granulosa cell luteinization and rat corpora lutea progesterone production (Gafvels et al. 1987, Baddela et al. 2018). Dysfunction of ovarian vasculature has been implicated in the pathophysiology of PCOS (Di Pietro et al. 2018), and additional studies are needed to address the pathologic role and therapeutic management of altered ovarian angiogenesis (Table 1).

\section{Nerves}

Neilson et al.'s (1970) review describes widespread innervation present in the ovarian stromal compartment, noting that some nerves follow blood vessels in the medulla while others branch among the cells in the stroma (Fig. 1 and Table 1). In mouse gonadal development, neural crest neurons colonize the ovary, differentiate into neurons and glia, and form dense neural networks in the medulla that extend toward cortical regions (McKey et al. 2019). Functionally, both sympathetic and parasympathetic innervation of the ovary has been demonstrated, and regulation by the sympathetic nervous system has been shown to inhibit estradiol secretion and cause vasoconstriction (reviewed in Uchida 2015). In a PCOS model, estradiol-treated rats demonstrated increased ovarian sympathetic activity and cystic anovulatory ovaries, with improvement noted in cyclicity and corpora lutea formation following superior ovarian nerve transection (Barria et al. 1993). Further study is warranted regarding the neuronal regulation of different cells types in the stroma, physiologic consequences of denervation, and neuronal contributions to pathology (Table 1).

\section{Lymphatic vessels}

Lymphatic vasculature includes small capillaries comprised of endothelial cells without a basement membrane that have large gaps between cells to allow fluid, cellular, and macromolecular transport. These capillaries feed into larger collecting vessels with basement membranes, valves, and smooth muscle (Fig. 1 and Table 1). The ovary has a rich lymphatic network, closely associating with blood vasculature, extending from the medulla into the cortex adjacent to developing follicles, with some species variability in regard to presence in the corpus luteum (Brown \& Russell 2014). The lymphatic system typically helps to maintain fluid homeostasis by returning extravascular fluid and proteins back to the bloodstream and participating in immune cell trafficking. In the developing mouse ovary, lymphatic vessels only appeared postnatally, potentially arising from the extraovarian rete ovarii, as seen in a Prox 1-EGFP mouse model, where Prox 1 expression marks the commitment of endothelial cells to the lymphatic lineage (Svingen et al. 2012). Lymphatic vasculature has been shown to remodel in response to hormonal regulation in mouse ovaries (Brown et al. 2010). Although lymphatic vasculature plays essential physiologic roles in the ovary, the dynamic regulation and pathologic relevance of the ovarian lymphatics remains to be fully elucidated (Table 1 ).

\section{Ovary-specific cell types of the ovarian stroma}

\section{Ovarian surface epithelium}

The surface epithelium of the ovary is a heterogenous flat to cuboidal epithelial layer derived from the mesoderm, also called the 'germinal epithelium' because of the false past belief that it contributed to germ cell formation (Auersperg et al. 2001) (Fig. 1 and Table 1). The keratin-rich ovarian surface epithelial cell layer helps to facilitate repair after ovulation and dynamically expands and contracts with cyclic ovarian changes (Xu et al. 2018, Hartanti et al. 2020). Scanning electron microscopy and immunofluorescence of the surface epithelium of developing fetal bovine ovaries demonstrated expansion from the hilar region to 
surround the entire ovary, with changes corresponding to underlying stromal rearrangement (Hartanti et al. 2020). Although fetal ovarian surface epithelial cells had been previously thought to be a developmental source for granulosa cells, more recent studies suggest that ovarian surface epithelial cells instead share a common progenitor with granulosa cells, known as the Gonadal Ridge Epithelial-Like (GREL) cell (Auersperg et al. 2001, Hummitzsch et al. 2013). Although definitive markers have not been identified, surface epithelial cells have increased expression of the cytokeratins 7, 8, 18, and 19 as well as plakophillin-2 and desmoglein-2 (Hummitzsch et al. 2013, Hartanti et al. 2020) (Table 1). Further work remains regarding identifying definitive markers, understanding heterogeneity, and clarifying the pathologic contributions of the ovarian surface epithelium.

\section{Tunica albuginea}

The ovarian tunica albuginea, positioned beneath the surface epithelium, is a thin and hypocellular connective tissue sheath, which serves as a protective layer for the ovary (Reeves 1971). The tunica albuginea is collagenrich and undergoes remodeling prior to ovulation. Using electron microscopy, Okamura et al. (1980) observed a decrease in presence of collagen bundles at the human follicular apex as follicles reached the preovulatory stage. This degradation was paralleled by an increase in apical fibroblasts with developed cytoplasm and lysosome-like granules, which were suspected to contain collagenases for degradation of the tunica albuginea (Okamura et al. 1980). There has been limited study of the ovarian tunica albuginea and further work can help to clarify physiologic and pathologic roles and regulation (Fig. 1 and Table 1).

\section{Intraovarian rete ovarii}

The rete ovarii are remnants of the mesonephric (Wolffian) ducts that typically form part of the male reproductive tract and regress in the female reproductive tract. They are often found as groups of tubules lined by cuboidal or columnar epithelium in the hilus of the ovary or extending through the medulla, as well as in the extraovarian space (reviewed in Wenzel \& Odend'hal 1985) (Fig. 1 and Table 1). There has been limited investigation into the function of the rete ovarii, particularly after development, where they may play relevant roles. In a study of murine theca cell lineages, one of the two identified progenitor populations of theca cells migrated from the adjacent mesonephros and was potentially related to the rete ovarii (Liu et al. 2015, Rotgers et al. 2018). Ovarian lymphatic vasculature origins have also been connected to the rete ovarii (Svingen et al. 2012). Although they are not necessarily specific markers, increased levels of cytokeratin 19 and vimentin have been noted in human rete ovarii (Russo et al. 2000). Further study is needed to elucidate the physiologic role of the rete ovarii in adults as well as the pathologic relevance (Table 1 ).

\section{Hilar cells}

There are reports of distinct cells located in the ovarian hilus with Reinke crystals, which are commonly found in testicular Leydig cells (Neilson et al. 1970) (Fig. 1 and Table 1). These cells are frequently located in clusters associated with a nerve trunk (Neilson et al. 1970). They appear to synthesize and secrete androgens in response to $\mathrm{LH}$ stimulation, although their physiologic role has not been well-established (Erickson et al. 1985). Hyperplasia of these hilar cells has been implicated in virilization in postmenopausal women (Delibasi et al. 2007). Cellular markers have not been established and the physiologic role and pathologic relevance of these cells remains generally uncharacterized.

\section{Ovarian stem cells}

The ovary may contain stem cells for a variety of different cell types, including somatic (e.g. granulosa, surface epithelial, thecal, stromal) and germline stem cells (reviewed in Hummitzsch et al. 2015) (Fig. 1 and Table 1). The presence and importance of ovarian germline (oogonial) stem cells has been a controversial topic, although the ovarian follicular reserve is generally lost with age without substantive renewal. Putative ovarian oogonial stem cells were first isolated through DEAD (Asp-Glu-Ala-Asp) box polypeptide 4 (DDX4, also known as VASA) tagging and cell sorting and have been shown to develop into oocytes, although isolation of DDX4 positive cells has been questioned, particularly related to assumptions about cytoplasmic vs surface expression and antibody cross-reactivity (Johnson et al. 2004, Zarate-Garcia et al. 2016). Others have disputed the presence of oogonial stem cells, noting that oogonial stem cells were not detectable using sensitive single-cell lineage tracing in adult female mice (Lei \& Spradling 2013). Additionally, postnatal DDX4-expressing cells generated using a Rosa26 $6^{r b w /+} ; D d x 4$-Cre fluorescent reporter mouse were not seen to be mitotically active nor participating in follicular renewal (Zhang et al. 2012). A recent single-cell sequencing study isolated human Abcam DDX4-positive cells and concluded these cells were perivascular cells rather than oogonial stem cells (Wagner et al. 2020). In contrast, cell line establishment of female germline stem cells has been described using cells from human ovarian cortical tissue fragments present in follicular aspirates, which differentiated into oocyte-like cells (Ding et al. 2016). Isolated, purified, and cultured female germline stem cells from an EGFP-transgenic mouse were shown 
to differentiate into oocytes, capable of restoring function and generating offspring in a mouse model of premature ovarian failure (Wu et al. 2017). The presence of ovarian germline stem cells continues to be a highly contested topic, generally eclipsing the discussion of somatic stem cells. The addition of human mesenchymal stem cells originating from amniotic fluid has also been used to help restore ovarian function in mouse models of premature ovarian failure, suggesting a role for somatic stem cells in improving altered paracrine signaling and the stroma microenvironment (Liu et al. 2019).

\section{Incompletely characterized stromal cells}

The majority of the ovarian stroma is comprised of a mixed population of incompletely characterized cells commonly referred to as stromal cells (Reeves 1971). This includes the populations of cells also described as fibroblast-like, spindle-shaped cells, or interstitial cells (Fig. 1 and Table 1). In general, fibroblasts secrete ECM proteins, such as collagen, for cellular support, scaffolding, and repair. A retrospective study of histologic sections from non-pathologic human ovaries from 167 women between the ages of 17 and 79 carried out with the goal of describing the morphology of various types of stromal cells identified five types of fibroblast-like/interstitial stromal cells (Reeves 1971). While recent human single-cell RNA-sequencing studies (e.g. Fan et al. 2019) confirm the presence of multiple stromal cell clusters, a comprehensive and complete characterization of stromal cell types throughout the ovary is lacking. The distribution and subtypes of stromal cells will likely differ with their location in the ovary (e.g. cortex vs medulla). The stromal cell distribution is also likely to be affected by cyclic structural changes, as follicles grow and ovulate and corpora lutea develop. Changes are also evident over the reproductive lifespan, including increases in fibrotic collagen as demonstrated in aging murine and primate ovaries (Briley et al. 2016, Wang et al. 2020). Some possible cellular markers that have been identified include COUP-TFII and/or ARX (Hummitzsch et al. 2013, Rotgers et al. 2018). Other studies have used DCN and LUM to identify populations of human theca/stroma cells (Fan et al. 2019). Higher expression in some of the human cells considered to be stroma was demonstrated for markers PDGFRA, DCN, COL1A1, COL6A1, STAR, and/or CYP17A1 (Wagner et al. 2020). A different study delineated nonhuman primate ovarian stroma by expression of TCF21, COL1A2, and/ or STAR (Wang et al. 2020). For these incompletely characterized stromal cell types, careful ontology, further marker identification, and attention to nuances of regionality and steroid production are critical next steps (Table 1).

\section{Extracellular matrix (ECM) components}

\section{Structure and definition}

The ECM is composed of fibril- and network-forming proteins, proteoglycans, and glycosaminoglycans, the composition of which is unique to each tissue (Fig. 1 and Table 1). Cells secrete soluble ECM components to the extracellular compartments where cell-secreted enzymes such as lysyl oxidase (LOX) crosslink the ECM precursors into large networks (Theocharis et al. 2016). These matrices regulate cellular functions including adhesion, migration, and proliferation through cell receptor interactions, mechanotransduction, and cell interaction with ECM-sequestered growth factors (Taipale \& Keski-Oja 1997).

Several reviews have covered the extensive list of ECM components that exist broadly in tissues and specifically in the ovary; most notably, collagen types I, III, IV, and VI, fibronectin, and laminin (Berkholtz et al. 2006, Irving-Rodgers \& Rodgers 2006). Collagens I and III have been shown to be distributed in concentric layers connected by bundles in human cortical stroma (Lind et al. 2006). A recent proteomic study examining the ECM of the human ovarian cortex revealed that collagens comprise nearly half of the ECM proteins and associated factors, the most dominant of which was collagen $\mathrm{VI}$, a basement membrane-anchoring ECM protein (Ouni et al. 2019). Another recent proteomic study examined ECM compositional differences between porcine cortex and medulla, showing increased expression of collagen I, agrin, elastin microfibril interfacer 1 , and fibronectin in the cortex compared to the medulla (Henning et al. 2019). These proteomic studies both identified over $80 \mathrm{ECM}$ and ECM-associated proteins, in categories of collagens, glycoproteins, proteoglycans, ECM-affiliated proteins, ECM regulators, and secreted factors (Henning et al. 2019, Ouni et al. 2019).

Many studies of ECM have focused on matrix within follicles during development. Follicles have a unique pericellular matrix called the basal lamina, composed primarily of laminin and type IV collagen stabilized by nidogen and perlecan which separates the granulosa and theca cell compartments (Irving-Rodgers \& Rodgers 2006). As follicles grow, they continuously remodel the basal lamina to allow for expansion of the follicle as granulosa cells proliferate. Granulosa cells have been shown to produce the major components of the basal lamina, although theca and other cells in the ovarian stroma may contribute to basal lamina deposition in later stages (Rodgers et al. 1999). The basal lamina also plays a role in mediating granulosa cell growth and antrum formation through growth factor sequestration and signaling. Perlecan in the basal lamina is able to bind growth factors and is charge and size selective, serving as a barrier for the diffusion of growth factors between the granulosa and theca cell compartments, 
allowing the follicular fluid and basal lamina to become reservoirs of factors to promote healthy folliculogenesis (McArthur et al. 2000).

\section{Mechanics}

The ovary has two major compartments which differ in their ECM composition and structure - a stiff cortex, where primordial follicles reside in dormancy, and a less dense medulla, where antral follicles vigorously remodel the ECM through proteolytic degradation as they reach preovulatory stages. Decellularized human and bovine ovarian tissue reveals radially aligned collagen fibers in the cortex, lending to its increased stiffness, whereas the medulla is composed of a network of pores with anisotropic collagen fibers, suggesting differences between cortical and medullary ECMproducing stromal cells (Laronda et al. 2015, Chiti et al. 2018). The prominence of ovarian cortical and medullary regionalization can differ across species and is notably reduced in rodent ovaries when compared to human ovaries (Jiménez 2009). The mechanical properties of these regions have important roles in mechanotransduction for the follicles as they activate and develop. Primordial follicle dormancy has been shown to be regulated by the Hippo signaling pathway, where rigidity of the ovarian cortex inactivates yes-associated protein (YAP) and transcriptional coactivator with PDZbinding motif (TAZ) to inhibit growth (Kawamura et al. 2013). Follicle activation can be initiated with disruption of the Hippo signaling pathway, for example, when follicles are isolated from the cortex, further illustrating the importance of ECM mechanical properties in maintenance of the follicular reserve (Kawamura et al. 2013). After activation, early stage follicle growth and survival is still dependent on a stiff matrix, as has been shown in vitro (Hornick et al. 2012). As follicles grow, they require a softer matrix for expansion as provided by the medullar region of the ovary, and in vitro studies have shown improved growth, survival, and steroidogenesis of later stage follicles in permissive matrices (West et al. 2007, West-Farrell et al. 2009).

\section{Function: signaling and remodeling}

ECM components play a large role in regulating cell functions through both direct and indirect signaling. Fibronectin and laminin contain integrin-binding sequences (most notably Arg-Gly-Asp, or RGD) which allow cells to directly interact with the ECM and initiate signaling cascades for proliferation and differentiation as follicles develop (Monniaux et al. 2006). ECM also has an indirect role in signaling as it acts as a reservoir of growth factors and cytokines and mediates their presentation to cells both when they are bound and when they are released upon ECM degradation. ECM is a dynamic structure in tissues, continuously being remodeled by the cells which reside in it through matrix metalloproteinases (MMPs), tissue inhibitors of matrix metalloproteinases (TIMPs), and plasminogen activators (Mclntush \& Smith 1998). Follicles and other ovarian stromal cells secrete these enzymes to soften the surrounding ECM and allow for follicular expansion, and in this process cytokines and growth factors bound to the ECM are released. Several growth factors known to be key regulatory molecules in folliculogenesis including fibroblast growth factor, transforming growth factor beta, platelet derived growth factor, hepatocyte growth factor, and insulin-like growth factor have ECM-binding motifs or can be sequestered within the ECM through binding factors such as follistatin (Logan \& Hill 1992). In this way, ECM remodeling is a mechanism by which growth factor bioavailability can be mediated or disrupted in some pathological conditions (McIntush \& Smith 1998). If dysregulated, ECM degradation may also trigger pathogen-free inflammation. For example, hyaluronan is a glycosaminoglycan that forms low molecular weight fragments during turnover, which have been shown in cultured murine stromal cells to increase the secretion of type 2 inflammatory cytokines and activate genes involved in eosinophil recruitment, while also leading to adverse effects on cultured follicles (Rowley et al. 2020).

At the final stages of follicular maturation the ECM again plays an important role in ovulation. Follicles are stimulated by the LH surge to produce large amounts of MMPs and plasminogen activator to degrade the ECM at the apical region of the follicle (Curry \& Smith 2006). This process is further amplified by the release of tumor necrosis factor-alpha (TNF-a) from the degraded ECM to promote collagenase production and apoptosis of ovarian epithelial cells (Curry \& Smith 2006). The weakened cellular and ECM components at the apical region, along with pressure from the follicular fluid and increased vascular pressure, facilitate follicular rupture and expulsion of the oocyte into the periovarian space (Matousek et al. 2001).

\section{Key areas for further research and future perspectives \\ Understanding the origins of the theca cells}

The theca cell layer is divided into the theca interna, with cytoplasmic lipid droplets characteristic of its role in steroid production, and the theca externa, which is a mix of fibroblasts and smooth muscle cells that are more contiguous with the broader ovarian stroma (reviewed in Young \& McNeilly 2010, Richards et al. 2018). The relationship between the supporting cells of the ovarian stroma and the theca cells has not been definitively established, although it is generally agreed that the theca cells originate at least in part from stromal cells (Young \& McNeilly 2010, Rotgers et al. 2018).

Murine theca cells have been shown to arise from two types of progenitors: Wt1-positive cells in the fetal ovary 
and Gli1-positive cells migrating from the mesonephros adjacent to the ovary (Liu et al. 2015). Near birth, desert hedgehog and Indian hedgehog paracrine signals from granulosa cells appear to prompt expression in undifferentiated stromal progenitor cells of the theca lineage marker Gli1. Microarray analysis suggested differences based on theca progenitor population, with increased steroidogenesis in the mesonephros-derived Gli1-positive cells (Liu et al. 2015). The steroidogenic androgen-producing theca cells may arise from the mesonephros derived progenitors, while the theca fibroblasts, perivascular smooth muscle cells, and possibly the interstitial ovarian cells may arise from the ovarian WT1+ progenitors (Richards et al. 2018).

Additional undifferentiated stromal cell progenitors (possibly positive for Lhx9, Mafb, Coup-tfll, and Arx) may yield a nonsteroidogenic stromal cell population, possibly expressing Coup-tfll and Arx. Overlapping expression of COUP-TFII and ARX in the same population of cells has not been established (Rotgers et al. 2018). Sonic hedgehog signaling has been shown to regulate expression of COUP-TFII, which was identified in murine theca interna cells and in mesenchymal cells around the corpus luteum (Krishnan et al. 1997, Takamoto et al. 2005). COUP-TFII is likely expressed in steroidogenic cells, as haploinsufficient female mice demonstrated altered reproduction function, including reduced expression of steroidogenic enzymes needed for progesterone synthesis and reduced vascularization (Takamoto et al. 2005). Three populations of somatic cell precursors have been demonstrated in murine fetal ovaries, marked by mutually exclusive expression of COUP-TFIl and the granulosa cell markers FOXL2 and LGR5 (Rastetter et al. 2014). Mutually exclusive FOXL2 and COUP-TFIl expression was also seen in early fetal human ovaries, with COUP-TFII expression in the stromal cell population. Several 46,XX SRY-negative children with mutations in the gene encoding COUPTFIl were virilized, with testicular tissue confirmed in one child, suggesting a 'pro-ovary' and 'anti-testis' role for COUP-TFII in developing human female gonads (Bashamboo et al. 2018).

A transgenic mouse study suggests the presence of at least two steroidogenic cell types for ovarian theca and interstitial gland cells. In postnatal mouse ovaries, only a portion of the steroidogenic theca and interstitial gland cells expressed enhanced green fluorescent protein (EGFP) as a reporter of the fetal Leydig enhancer (FLE) of the Nr5a1 gene (SF-1). SF-1 regulates expression of steroidogenic CYP genes. In testes, the FLE differentiates fetal from adult Leydig cells. However, in the postnatal mouse ovaries only approximately $16 \%$ of the SF- 1 postive cells were positive for EGFP, suggesting at least two cell populations (Miyabayashi et al. 2015).

A transcriptome analysis of the bovine ovarian stroma found that populations isolated by laser microdissection were similar between general interstitial stroma and what they labeled as pre-theca cells (stroma adjacent to preantral follicles). They combined them for the purpose of analysis, and the subsequent stroma was found to be different from both the tunica albuginea and the theca interna (Hummitzsch et al. 2019). The theca interna of small antral follicles had an upregulation of genes associated with steroid hormone and cholesterol synthesis as compared to the stroma (Hummitzsch et al. 2019).

Of note, the concept of theca interstitial cells (TICs) has been used as a catch-all for the residual ovarian tissue husk once follicles had been punctured (Tingen et al. 2011, Tian et al. 2015). When cultured, theca interstitial cells from mouse ovaries take on a fibroblastlike appearance that is distinct from granulosa cells (Tian et al. 2015). The heterogeneity of the TICs has been noted, with a reported shift in populations over a 12-day co-culture with follicles. At the beginning of the culture, the population contained predominantly lipid droplet-containing cells resembling theca cells as well as fibroblast-like cells, whereas the cells were mainly macrophages by day 12 (Tingen et al. 2011). This transition in cell phenotype may be due to differential survival in culture of the different starting cell populations, emphasizing that TICs are not a homogenous grouping.

Further understanding the stromal compartment may aid in better identification of theca progenitors (Fig. 2). Additionally, studies using mixed populations of TICs may benefit from greater categorization of these non-follicular populations to aid in interpretation and reproducibility of findings.

\section{Stromal cell hormone production and responsiveness}

Some of the ovarian stromal cells are capable of steroid hormone production and contain hormone receptors. For instance, estrogen receptor alpha and beta have been identified in the cytoplasm and nucleus of bovine interstitial cells, which were described as oval cells with lipid droplets and vacuoles that were distinguishable

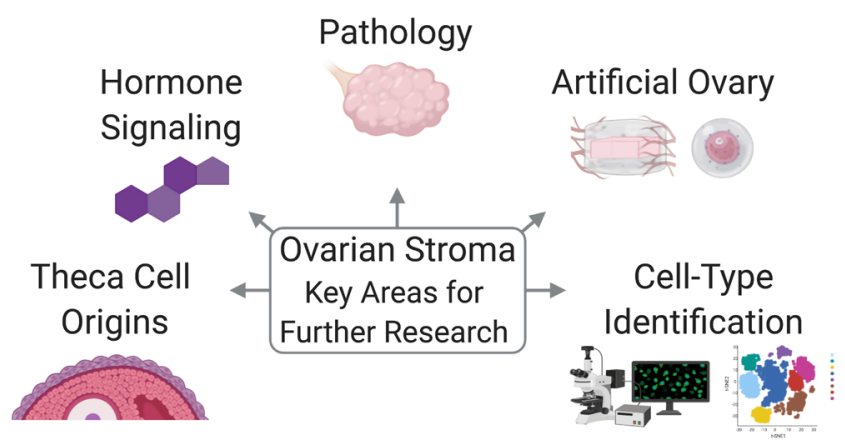

Figure 2 Ovarian stroma key areas for further research. Includes (clockwise from left): theca cell origins, hormone signaling, pathology, artificial ovary, and cell-type identification. Made using CBioRender - biorender.com. 
from fibroblasts (Kenngott et al. 2016). Progesterone receptor alpha has been identified in stromal cells and interstitial cells of pregnant and post-partum rabbit ovaries (Abd-Elkareem 2017). Interstitial cells with features of steroid production have been documented in early gestation in the human fetal ovary (Konishi et al. 1986). Postmenopausal ovarian stromal cells have been postulated to produce androgens, although a study of in vitro isolated postmenopausal human stromal cells found that the predominant population had negligible expression of a key steroidogenic enzyme in the androgen biosynthesis pathway, CYP17A1, and did not appear to have significant steroidogenic potential (Jabara et al. 2003). Additionally, they found that transcripts for certain steroidogenic enzymes (STAR, CYP11A1, and $H S D 3 B$ ) were much less abundant in the in vitro isolated stromal cells than in theca cells, with the exception of STAR which had more transcript abundance in stromal cells than in fibroblasts (Jabara et al. 2003). In contrast, localization of CYP17A1 shifted from exclusively the theca interna in control mice to patches in the interstitial stroma in DHT-treated mice, supporting a potential role for the stroma in androgen production following certain perturbations (Candelaria et al. 2019). Singlecell RNA sequencing studies have also demonstrated subpopulations of stromal cells expressing CYP17A1 and STAR (Wagner et al. 2020, Wang et al. 2020). Although stromal cells have demonstrated varied hormone production and responsiveness, definitive characterization of these dynamics and their functional significance remains to be established (Fig. 2).

\section{Pathological ovarian stromal changes: polycystic ovary syndrome as an example}

Polycystic ovary syndrome (PCOS) has been defined by the Rotterdam Criteria (2004) as two of the three characteristics: hyperandrogenism, oligo or amenorrhea, and follicular cysts as noted on ultrasound (The Rotterdam ESHRE/ASRM-Sponsored PCOS Consensus Workshop Group 2004). Polycystic ovarian morphology includes the following features: thickening of the tunica albuginea, ovarian stromal hyperplasia, stromal cell luteinization, and large cystic antral follicles (Hughesdon 1982). The thickness of the cortical stroma is increased by one-third and the subcortical stroma by five-fold (Hughesdon 1982). In detailed ultrasound assessment, women with PCOS were found to have significantly increased ovarian volume, stromal volume, and stromal peak blood flow velocity as compared to controls (Buckett et al. 1999). In contrast, no difference was found in ovarian stromal blood flow between women with PCOS and a control group explicitly excluding patients with low ovarian reserve (Younis et al. 2011). The ratio of ovarian stromal area to total ovarian area (S/A) by ultrasound was a good predictor of hyperandrogenism in lean Italian women with PCOS, with increased ovarian vascularization and blood flow noted in PCOS patients as compared to controls (Battaglia et al. 2012), and S/A ratio has been proposed as a method to refine the Rotterdam PCOS classification (Belosi et al. 2006). In contrast, the S/A ratio was found to have limited predictive value as a PCOS diagnostic in reproductive-aged Thai women with PCOS (Leerasiri et al. 2015). Another study found increased ovarian stromal area with PCOS, but was unable to demonstrate a relationship between stromal area and PCOS hormonal characteristics (Kaleli et al. 1998). Ovarian angiogenesis dysfunction including increased ovarian stromal vascularization, lower impedance to flow (Alcázar \& Kudla 2012), and alterations in angiogenic factors levels in PCOS have been further reviewed elsewhere (Di Pietro et al. 2018), with possible implications that restoration of appropriate vessel formation could improve folliculogenesis and ovulation. Inflammation-related gene expression was downregulated in the ovarian stroma and upregulated in granulosa cells for PCOS women as compared to controls, although the downregulation in the stroma may have been affected by a reduced abundance of leukocytes in the PCOS stroma as measured by CD45 mRNA levels (Schmidt et al. 2014). A reduction in thecaassociated activated/memory $\mathrm{T}$ lymphocytes has also been seen in PCOS ovaries as compared to controls, without notable differences in macrophage or neutrophil levels across multiple ovarian compartments (Wu et al. 2007). Broadly, PCOS may impact stromal volume, tunica albuginea thickness, stromal luteinization, vascularization, blood flow, inflammation and immune cell distribution, although the causes and functional impacts of these stromal changes have not been fully elucidated.

Hyperandrogenism, one of the common aspects of PCOS, has been shown to drive certain stromal alterations. For instance, in transgender men given exogenous testosterone therapy, increases were noted in tunica albuginea collagenization, stromal hyperplasia, and stromal luteinization with clusters of luteinized stromal cells (Spinder et al. 1989, Ikeda et al. 2013), as well as increased stromal androgen receptor staining (Chadha et al. 1994). Multiple cell types in polycystic ovaries may produce androgens, as immunohistochemistry revealed the presence of steroidogenic enzymes for androgen synthesis in follicular theca cells, luteinized stromal cells, hilar cells, and sporadic non-luteinized stromal cells (Kaaijk et al. 2000). Mice treated with dihydrotestosterone (DHT) also demonstrated stromal changes, including less dense, hyperplastic, and lipidfilled stroma when compared to age-matched controls. These mice also had an overexpression of multiple genes in the mechanically separated stroma between controls and DHT-treated mice (Candelaria et al. 2019). This included increased Vcam 1 expression (which may impact vascular and immune responses) in thecal and stromal cells, while theca-specific androgen 
receptor knockout mice (ThARKO, Cyp17a1-iCre, $\mathrm{AR}^{\mathrm{f} / \mathrm{f}}$ mice) demonstrated a lack of DHT-induced Vcam 1 elevation (Richards et al. 2018, Candelaria et al. 2019). ThARKO mice were also shown to retain much of their reproductive function, including cyclicity and fertility, as compared to controls when treated with DHT (Ma et al. 2017). For mice with DHT-induced stromal changes, superovulation rescued at least some of the abnormal stromal morphology (Candelaria et al. 2019).

Several changes occur in the ovarian ECM in polycystic ovary syndrome. The cortex and basal laminas of follicles thicken and become more collagenous with reduced glycosaminoglycan content (Salvetti et al. 2003). A comparison of human PCOS to control ovaries in both the follicular and luteal phases revealed significantly lower pro-collagen IV expression compared to control ovaries, and this decrease in collagen IV was postulated to contribute to premature luteinization (Oksjoki et al. 2004). PCOS patients tend to have increased MMP-9 secretion as well, which may be related to the inability of follicles to undergo normal atresia (Dambala et al. 2019).

\section{Stromal contribution to artificial ovary technology}

The term 'artificial ovary' typically references ovarian follicles (or hormone-producing cell types) within a supportive scaffold (Fig. 2). The creation of an artificial ovary as a means of fertility preservation and endocrine support has been a persistent challenge from biological and engineering perspectives, as follicle development requires a complex symphony of soluble signals and mechanical cues, some of which may derive from the ovarian stroma.

Co-culture of follicles with stromal feeder cells has shown promise for providing the key soluble factors to promote growth of early stage murine follicles in vitro (Tingen et al. 2011). With regard to directly sourcing ovarian stromal cells, ideal collection strategies may differ between stromal cells and follicles. Human stromal cells have been shown to be better preserved after vitrification than slow freezing, with slow freezing increasing necrosis and collagen bundle disruption in the stromal cells, while follicles were similarly preserved in both vitrification and slow freezing (Keros et al. 2009). Isolating human stromal cells from fresh medullary tissue was shown to be superior to isolation from ovarian cortex in slow frozen and fresh samples and led to increased cell yield, better viability, and improved vascularization when encapsulated in fibrin and implanted in the peritoneal pockets of nude mice (Soares et al. 2015). For xenograft models, the importance of transplanting stromal endothelial cells has been demonstrated (Dath et al. 2011). Isolated human ovarian cortical stromal cell suspensions containing stromal endothelial cells yielded well-vascularized and organized grafts after a 1-week implantation in mice, in contrast to grafts depleted of stromal endothelial cells, which were smaller, necrotic, and poorly vascularized (Dath et al. 2011).

It is also challenging to develop a supportive scaffold that fully recapitulates the ovarian ECM. Multiple 3D hydrogel culture systems such as alginate, fibrin, and poly(ethylene glycol) (PEG) aim to recapitulate the mechanical properties of the ovarian environment to maintain the spherical structure of follicles and allow for their expansion; however, these systems are lacking the biological functionality of ECM and the ability to sequester growth factors (Luyckx et al. 2014, Smith et al. 2014, Kniazeva et al. 2015, Kim et al. 2016, Chiti et al. 2018, Rios et al. 2018). Several groups have attempted to restore the biological function of ECM in these artificial ovaries by encapsulating follicles in ECM matrices such as Matrigel or decellularized tissues (Scott et al. 2004, Laronda et al. 2015). Unfortunately, these matrices do not include all of the components present in native ovarian ECM and also face challenges in translation in regard to availability of tissue and batch-to-batch variability.

While each of these systems incorporates key components necessary for follicle growth, there is yet to be a system that truly mimics the ovarian microenvironment in both complexity of cell populations and extracellular matrix composition which can be translated for clinical use. Part of this limitation relates to scarcity of knowledge as it pertains to the cell types and functions of the ovarian stroma.

\section{Identification of ovarian stromal cells}

The multiple populations of cells referred to as stromal cells are incompletely characterized and categorized, leading to confusion across studies that report findings about stromal cells without further identification (Fig. 2). Regional differences (e.g. cortex vs medulla) likely influence the distribution and subtypes of stromal cells. Immunofluorescent imaging using known markers for follicular or stromal cells has advanced our understanding of the ovarian stroma, including the delineation of at least two distinct populations of steroidogenic theca and interstitial gland cells in postnatal murine ovaries, as well as the identification of at least three different somatic cell lineages in murine fetal ovaries (Rastetter et al. 2014, Miyabayashi et al. 2015). With developments in single-cell sequencing technologies to complement these detailed imaging studies, we may soon have the ability to better characterize the cells commonly called stromal cells and refer to them with more precise names as we understand their individual roles in physiologic and pathologic processes.

Single-cell RNA-sequencing experiments have already made progress in identifying major ovarian cell types, transition stages, and markers for cell identification. These studies have significantly contributed to mapping the signatures of human and murine oocytes and 
granulosa cells from multiple follicular stages (Zhang et al. 2018). Yet, data about the ovarian stroma remain elusive and comparatively scarce. An investigation of somatic cells only in the inner cortex was performed in women undergoing fertility preservation procedures, detecting five clusters of granulosa cells, five clusters of theca and stromal cells, two clusters of smooth muscle cells, three clusters of endothelial cells, and four clusters of immune cells (Fan et al. 2019). They confirmed the presence of adaptive immune cells including $\mathrm{T}$ lymphocytes, Natural Killer cells, and B lymphocytes, as well as innate immune cells including monocytes and macrophages. This study also identified upregulation of the complement system (including C1R, C1S, and C7) by theca and stromal cells as a potential contributor to ovarian tissue remodeling (Fan et al. 2019). A subsequent single-cell analysis of the human ovarian cortex reported six clusters, including oocytes, granulosa cells, immune cells, endothelial cells, perivascular cells, and stromal cells. They classified a majority of cells (83\%) as stroma, noting shared expression of mesodermal lineage markers (PDGFRA, DCN), ECM proteins (COL1A1, COL6A1), as well as expression of STAR and CYP17A1 by some cells in the stromal cluster. Although they isolated many stromal cells, their study mainly focused on discerning whether cells isolated using the Abcam DDX4 antibody were oogonial stem cells (Wagner et al. 2020). A single-cell transcriptomic study of ovarian aging in nonhuman primate ovaries identified seven ovarian cell types, including oocytes, granulosa cells, stromal cells, smooth muscle cells, endothelial cells, Natural Killer T cells, and macrophages (Wang et al. 2020). The stromal cell cluster specifically expressed TCF21 and COL1A2, with some cells in the stromal cluster expressing high levels of STAR (Wang et al. 2020). A time series single-cell RNA sequencing study was performed for cells labeled with the gonadal somatic cell marker Nr5a1 (steroidogenic factor 1, SF-1) in the developing mouse ovary from E10.5 to postnatal day 6 . Four distinct populations, including early progenitors, stromal progenitors, pre-granulosa cells, and postnatal granulosa cells, were identified from their sequencing. Using their time series, they analyzed cell conversion from early progenitors to both the stromal progenitor lineage (E13.5) and the granulosa cell lineages (E11.5E12.5) (Stévant et al. 2019). These studies are supported by precise immunofluorescent characterization of at least three somatic cell populations in fetal mouse ovaries, including COUP-TFII-positive possible pretheca progenitors, LGR5-positive cortical granulosa cell progenitors, and FOXL2-positive medullary granulosa cell progenitors (Rastetter et al. 2014). Although singlecell sequencing studies allow for greater granularity in understanding the nuance of different ovarian cellular populations, including the stroma, it remains important to continually reflect on the possible limitations of any starting cellular populations (e.g. inner cortex only), with the overall goal of broadening our understanding of the entire ovarian microenvironment.

\section{Future perspectives}

As the majority of ovarian research studies focus on the ovarian follicles, a thorough understanding of the components and functions of the ovarian stroma is an active area of current research. The support provided by the ovarian stroma is essential for 3D follicular maintenance and the integration of signals to support folliculogenesis. The stromal compartment is heterogeneous and analyses using bulk methods or gross dissection may lose the granularity that could be observed between low density specialized cellular populations. In addition to precise immunohistochemical and immunofluorescent studies for specific stromal cell population identification and lineage tracing, singlecell sequencing studies will continue to allow for more in-depth analysis of physiologic and pathologic changes occurring to specific cell types that might otherwise be grouped together. These sequencing studies must be conducted with critical reflection on the specifics of the origin of the sequenced cells. Greater understanding and careful ontology of the different populations of stromal cells would reduce ambiguity between studies. Further study integrating phenotypic changes in specific stromal cellular populations with functional changes would also help determine how changes in the ovarian stroma occur over time and may interact with folliculogenesis, position, and hormone production.

\section{Declaration of interest}

Vasantha Padmanabhan is an Associate Editor of Reproduction. Vasantha Padmanabhan was not involved in the review or editorial process for this paper, on which she is listed as an author. The other authors have nothing to disclose.

\section{Funding}

This work was supported by the National Institutes of Health (R01-EB022033 to A S, R01-HD098233 to M B M, P01-HD044232 to V P, F30-HD100163 and T32-HD079342 to H M K, F31-HD100069 and T32-DE007057 to C E T); NSF CAREER (1552580 to A S); American Society for Reproductive Medicine/Society for Reproductive Endocrinology and Infertility Grant to M B M; Chan Zuckerberg Initiative Human Cell Atlas of the Female Reproductive System to A S; and University of Michigan Office of Research funding (U058227) to $\mathrm{MB}$ M.

\section{Author contribution statement}

H M K, A S and V P conceived and drafted the review. A S provided oversight. $\mathrm{H} \mathrm{MK}$ and $\mathrm{C}$ E T wrote the review. 
$\mathrm{F} L \mathrm{C}$ revised the figures. $\mathrm{M} B \mathrm{M}, \mathrm{MX}$ and $\mathrm{F} \mathrm{L} C$ provided critical input and edits. All authors read and approved the final version.

\section{References}

Abd-Elkareem M 2017 Cell-specific immuno-localization of progesterone receptor alpha in the rabbit ovary during pregnancy and after parturition. Animal Reproduction Science 180 100-120. (https://doi.org/10.1016/j. anireprosci.2017.03.007)

Alcázar JL \& Kudla MJ 2012 Ovarian stromal vessels assessed by spatiotemporal image correlation-high definition flow in women with polycystic ovary syndrome: a case-control study. Ultrasound in Obstetrics and Gynecology 40 470-475. (https://doi.org/10.1002/uog.11187)

Auersperg N, Wong AST, Choi KC, Kang SK \& Leung PCK 2001 Ovarian surface epithelium: biology, endocrinology, and pathology. Endocrine Reviews 22 255-288. (https://doi.org/10.1210/edrv.22.2.0422)

Baddela VS, Sharma A, Viergutz T, Koczan D \& Vanselow J 2018 Low oxygen levels induce early luteinization associated changes in bovine granulosa cells. Frontiers in Physiology 9 1066. (https://doi.org/10.3389/ fphys.2018.01066)

Barria A, Leyton V, Ojeda SR \& Lara HE 1993 Ovarian steroidal response to gonadotropins and $\beta$-adrenergic stimulation is enhanced in polycystic ovary syndrome: role of sympathetic innervation. Endocrinology 133 2696-2703. (https://doi.org/10.1210/endo.133.6.8243293)

Bashamboo A, Eozenou C, Jorgensen A, Bignon-Topalovic J, Siffroi JP, Hyon C, Tar A, Nagy P, Sólyom J, Halász Z et al. 2018 Loss of function of the nuclear receptor NR2F2, encoding COUP-TF2, causes testis development and cardiac defects in 46,XX children. American Journal of Human Genetics 102 487-493. (https://doi.org/10.1016/j.ajhg.2018.01.021)

Battaglia C, Battaglia B, Morotti E, Paradisi R, Zanetti I, Meriggiola MC \& Venturoli S 2012 Two- and three-dimensional sonographic and color Doppler techniques for diagnosis of polycystic ovary syndrome. The stromal/ovarian volume ratio as a new diagnostic criterion. Journal of Ultrasound in Medicine 31 1015-1024. (https://doi.org/10.7863/ jum.2012.31.7.1015)

Belosi C, Selvaggi L, Apa R, Guido M, Romualdi D, Fulghesu AM \& Lanzone A 2006 Is the PCOS diagnosis solved by ESHRE/ASRM 2003 consensus or could it include ultrasound examination of the ovarian stroma? Human Reproduction 21 3108-3115. (https://doi.org/10.1093/ humrep/del306)

Berkholtz CB, Shea LD \& Woodruff TK 2006 Extracellular matrix functions in follicle maturation. Seminars in Reproductive Medicine 24 262-269. (https://doi.org/10.1055/s-2006-948555)

Briley SM, Jasti S, McCracken JM, Hornick JE, Fegley B, Pritchard MT \& Duncan FE 2016 Reproductive age-associated fibrosis in the stroma of the mammalian ovary. Reproduction 152 245-260. (https://doi. org/10.1530/REP-16-0129)

Brown HM \& Russell DL 2014 Blood and lymphatic vasculature in the ovary: development, function and disease. Human Reproduction Update 20 29-39. (https://doi.org/10.1093/humupd/dmt049)

Brown HM, Robker RL \& Russell DL 2010 Development and hormonal regulation of the ovarian lymphatic vasculature. Endocrinology 151 5446-5455. (https://doi.org/10.1210/en.2010-0629)

Buckett WM, Bouzayen R, Watkin KL, Tulandi T \& Tan SL 1999 Ovarian stromal echogenicity in women with normal and polycystic ovaries. Human Reproduction 14 618-621. (https://doi.org/10.1093/ humrep/14.3.618)

Candelaria NR, Padmanabhan A, Stossi F, Ljungberg MC, Shelly KE, Pew BK, Solis M, Rossano AM, McAllister JM, Wu S et al. 2019 VCAM1 is induced in ovarian theca and stromal cells in a mouse model of androgen excess. Endocrinology 160 1377-1393. (https://doi. org/10.1210/en.2018-00731)

Care AS, Diener KR, Jasper MJ, Brown HM, Ingman WV \& Robertson SA 2013 Macrophages regulate corpus luteum development during embryo implantation in mice. Journal of Clinical Investigation 123 3472-3487. (https://doi.org/10.1172/JCl60561)

Carlock C, Wu J, Zhou C, Ross A, Adams H \& Lou Y 2013 Ovarian phagocyte subsets and their distinct tissue distribution patterns. Reproduction 146 491-500. (https://doi.org/10.1530/REP-13-0134)
Chadha S, Pache TD, Huikeshoven JM, Brinkmann AO \& van der Kwast TH 1994 Androgen receptor expression in human ovarian and uterine tissue of long term androgen-treated transsexual women. Human Pathology 25 1198-1204. (https://doi.org/10.1016/0046-8177(94)90037-x)

Chiti MC, Dolmans MM, Mortiaux L, Zhuge F, Ouni E, Shahri PAK, Van Ruymbeke E, Champagne SD, Donnez J \& Amorim CA 2018 A novel fibrin-based artificial ovary prototype resembling human ovarian tissue in terms of architecture and rigidity. Journal of Assisted Reproduction and Genetics 35 41-48. (https://doi.org/10.1007/s10815-017-1091-3)

Curry TE \& Smith MF 2006 Impact of extracellular matrix remodeling on ovulation and the Folliculo-luteal transition. Seminars in Reproductive Medicine 24 228-241. (https://doi.org/10.1055/s-2006-948552)

Dambala K, Paschou SA, Michopoulos A, Siasos G, Goulis DG, Vavilis D \& Tarlatzis BC 2019 Biomarkers of endothelial dysfunction in women with polycystic ovary syndrome. Angiology 70 797-801. (https://doi. org/10.1177/0003319719840091)

Dath C, Dethy A, Van Langendonckt A, Van Eyck AS, Amorim CA, Luyckx V, Donnez J \& Dolmans MM 2011 Endothelial cells are essential for ovarian stromal tissue restructuring after xenotransplantation of isolated ovarian stromal cells. Human Reproduction 26 1431-1439. (https://doi.org/10.1093/humrep/der073)

Delibasi T, Erdogan MF, Serinsöz E, Kaygusuz G, Erdogan G \& Sertçelik A 2007 Ovarian hilus-cell hyperplasia and high serum testosterone in a patient with postmenopausal virilization. Endocrine Practice 13 472-475. (https://doi.org/10.4158/EP.13.5.472)

Di Pietro M, Pascuali N, Parborell F \& Abramovich D 2018 Ovarian angiogenesis in polycystic ovary syndrome. Reproduction 155 R199-R209. (https://doi.org/10.1530/REP-17-0597)

Ding X, Liu G, Xu B, Wu C, Hui N, Ni X, Wang J, Du M, Teng X \& Wu J 2016 Human GV oocytes generated by mitotically active germ cells obtained from follicular aspirates. Scientific Reports 6 28218. (https:// doi.org/10.1038/srep28218)

Erickson GF, Magoffin DA, Dyer CA \& Hofeditz C 1985 The ovarian androgen producing cells: a review of structure/function relationships. Endocrine Reviews 6 371-399. (https://doi.org/10.1210/edrv-6-3-371)

Fan X, Bialecka M, Moustakas I, Lam E, Torrens-Juaneda V, Borggreven NV, Trouw L, Louwe LA, Pilgram GSK, Mei H et al. 2019 Single-cell reconstruction of follicular remodeling in the human adult ovary. Nature Communications 10 3164. (https://doi.org/10.1038/ s41467-019-11036-9)

Gafvels M, Selstam G \& Damber JE 1987 Influence of oxygen tension and substrates on basal and luteinizing hormone stimulated progesterone production and energy metabolism by isolated corpora lutea of adult pseudopregnant rats. Acta Physiologica Scandinavica 130 475-482. (https://doi.org/10.1111/j.1748-1716.1987.tb08164.x)

Gray H 1918 Anatomy of the Human Body. Philadelphia and New York: Lea \& Febiger.

Hartanti MD, Hummitzsch K, Bonner WM, Bastian NA, Irving-Rodgers HF \& Rodgers RJ 2020 Formation of the bovine ovarian surface epithelium during fetal development. Journal of Histochemistry and Cytochemistry 68 113-126. (https://doi.org/10.1369/0022155419896797)

Henning NF, LeDuc RD, Even KA \& Laronda MM 2019 Proteomic analyses of decellularized porcine ovaries identified new matrisome proteins and spatial differences across and within ovarian compartments. Scientific Reports 9 20001. (https://doi.org/10.1038/s41598-019-56454-3)

Hornick JE, Duncan FE, Shea LD \& Woodruff TK 2012 Isolated primate primordial follicles require a rigid physical environment to survive and grow in vitro. Human Reproduction 27 1801-1810. (https://doi. org/10.1093/humrep/der468)

Hughesdon PE 1982 Morphology and morphogenesis of the stein-leventhal ovary and of so-called 'hyperthecosis'. Obstetrical and Gynecological Survey 37 59-77. (https://doi.org/10.1097/00006254-198202000-00001)

Hummitzsch K, Irving-Rodgers HF, Hatzirodos N, Bonner W, Sabatier L, Reinhardt DP, Sado Y, Ninomiya Y, Wilhelm D \& Rodgers RJ 2013 A new model of development of the mammalian ovary and follicles. PLoS ONE 8 e55578. (https://doi.org/10.1371/journal.pone.0055578)

Hummitzsch K, Anderson RA, Wilhelm D, Wu J, Telfer EE, Russell DL, Robertson SA \& Rodgers RJ 2015 Stem cells, progenitor cells, and lineage decisions in the ovary. Endocrine Reviews 36 65-91. (https://doi. org/10.1210/er.2014-1079)

Hummitzsch K, Hatzirodos N, Macpherson AM, Schwartz J, Rodgers RJ \& Irving-Rodgers HF 2019 Transcriptome analyses of ovarian stroma: 
tunica albuginea, interstitium and theca interna. Reproduction 157 545-565. (https://doi.org/10.1530/REP-18-0323)

Ikeda K, Baba T, Noguchi H, Nagasawa K, Endo T, Kiya T \& Saito T 2013 Excessive androgen exposure in female-to-male transsexual persons of reproductive age induces hyperplasia of the ovarian cortex and stroma but not polycystic ovary morphology. Human Reproduction $\mathbf{2 8}$ 453-461. (https://doi.org/10.1093/humrep/des385)

Irving-Rodgers HF \& Rodgers RJ 2006 Extracellular matrix of the developing ovarian follicle. Seminars in Reproductive Medicine 24 195-203. (https://doi.org/10.1055/s-2006-948549)

Jabara S, Christenson LK, Wang CY, McAllister JM, Javitt NB, Dunaif A \& Strauss JF 2003 Stromal cells of the human postmenopausal ovary display a distinctive biochemical and molecular phenotype. Journal of Clinical Endocrinology and Metabolism 88 484-492. (https://doi. org/10.1210/jc.2002-021274)

Jiménez R 2009 Ovarian organogenesis in mammals: mice cannot tell us everything. Sexual Development 3 291-301. (https://doi. org/10.1159/000280584)

Johnson J, Canning J, Kaneko T, Pru JK \& Tilly JL 2004 Germline stem cells and follicular renewal in the postnatal mammalian ovary. Nature $\mathbf{4 2 8}$ 145-150. (https://doi.org/10.1038/nature02316)

Kaaijk EM, Sasano H, Suzuki T, Beek JF \& van der Veen F 2000 Distribution of steroidogenic enzymes involved in androgen synthesis in polycystic ovaries: an immunohistochemical study. Molecular Human Reproduction 6 443-447. (https://doi.org/10.1093/molehr/6.5.443)

Kaleli S, Erel CT, Oral E, Elter K, Akman C \& Colgar U 1998 Ovarian stromal hypertrophy in polycystic ovary syndrome. Journal of Reproductive Medicine 43 893-897.

Kawamura K, Cheng Y, Suzuki N, Deguchi M, Sato Y, Takae S, Ho CH, Kawamura N, Tamura M, Hashimoto S et al. 2013 Hippo signaling disruption and Akt stimulation of ovarian follicles for infertility treatment. PNAS 110 17474-17479. (https://doi.org/10.1073/pnas.1312830110)

Kenngott RAM, Scholz W \& Sinowatz F 2016 Ultrastructural aspects of the prenatal bovine ovary differentiation with a special focus on the interstitial cells. Anatomia, Histologia, Embryologia 45 357-366. (https:// doi.org/10.1111/ahe.12203)

Keros V, Xella S, Hultenby K, Pettersson K, Sheikhi M, Volpe A, Hreinsson J \& Hovatta O 2009 Vitrification versus controlled-rate freezing in cryopreservation of human ovarian tissue. Human Reproduction 24 1670-1683. (https://doi.org/10.1093/humrep/dep079)

Kim J, Perez AS, Claflin J, David A, Zhou H \& Shikanov A 2016 Synthetic hydrogel supports the function and regeneration of artificial ovarian tissue in mice. NPJ Regenerative Medicine 1 16010. (https://doi. org/10.1038/npjregenmed.2016.10)

Kizuka-Shibuya F, Tokuda N, Takagi K, Adachi Y, Lee L, Tamura I, Maekawa R, Tamura H, Suzuki T, Owada Y et al. 2014 Locally existing endothelial cells and pericytes in ovarian stroma, but not bone marrowderived vascular progenitor cells, play a central role in neovascularization during follicular development in mice. Journal of Ovarian Research 710. (https://doi.org/10.1186/1757-2215-7-10)

Kniazeva E, Hardy AN, Boukaidi SA, Woodruff TK, Jeruss JS \& Shea LD 2015 Primordial follicle transplantation within designer biomaterial grafts produce live births in a mouse infertility model. Scientific Reports 5 17709. (https://doi.org/10.1038/srep17709)

Kong LL, Yang NZ, Shi LH, Zhao GH, Zhou W, Ding Q, Wang MH \& Zhang YS 2017 The optimum marker for the detection of lymphatic vessels. Molecular and Clinical Oncology 7 515-520. (https://doi. org/10.3892/mco.2017.1356)

Konishi I, Fujii S, Okamura H, Parmley T \& Mori T 1986 Development of interstitial cells and ovigerous cords in the human fetal ovary: an ultrastructural study. Journal of Anatomy 148 121-135.

Krishnan V, Pereira FA, Qiu Y, Chen CH, Beachy PA, Tsai SY \& Tsai MJ 1997 Mediation of sonic hedgehog-induced expression of COUP-TFII by a protein phosphatase. Science 278 1947-1950. (https://doi.org/10.1126/ science.278.5345.1947)

Laronda MM, Jakus AE, Whelan KA, Wertheim JA, Shah RN \& Woodruff TK 2015 Initiation of puberty in mice following decellularized ovary transplant. Biomaterials 50 20-29. (https://doi.org/10.1016/j. biomaterials.2015.01.051)

Leerasiri P, Wongwananuruk T, Rattanachaiyanont $M$, Indhavivadhana $S$, Techatraisak K \& Angsuwathana S 2015 Ratio of ovarian stroma and total ovarian area by ultrasound in prediction of hyperandrogenemia in reproductive-aged Thai women with polycystic ovary syndrome: a diagnostic test. Journal of Obstetrics and Gynaecology Research 41 248-253. (https://doi.org/10.1111/jog.12514)

Lei L \& Spradling AC 2013 Female mice lack adult germ-line stem cells but sustain oogenesis using stable primordial follicles. PNAS 110 8585-8590. (https://doi.org/10.1073/pnas.1306189110)

Lind AK, Weijdegård B, Dahm-Kähler P, Mölne J, Sundfeldt K \& Brännström M 2006 Collagens in the human ovary and their changes in the perifollicular stroma during ovulation. Acta Obstetricia et Gynecologica Scandinavica 85 1476-1484. (https://doi. org/10.1080/00016340601033741)

Liu C, Peng J, Matzuk MM \& Yao HHC 2015 Lineage specification of ovarian theca cells requires multicellular interactions via oocyte and granulosa cells. Nature Communications 6 6934. (https://doi. org/10.1038/ncomms7934)

Liu R, Zhang X, Fan Z, Wang Y, Yao G, Wan X, Liu Z, Yang B \& Yu L 2019 Human amniotic mesenchymal stem cells improve the follicular microenvironment to recover ovarian function in premature ovarian failure mice. Stem Cell Research and Therapy 10 299. (https://doi. org/10.1186/s13287-019-1315-9)

Logan A \& Hill DJ 1992 Bioavailability: is this a key event in regulating the actions of peptide growth factors? Journal of Endocrinology 134 157-161. (https://doi.org/10.1677/joe.0.1340157)

Luyckx V, Dolmans MM, Vanacker J, Legat C, Fortuño Moya C, Donnez J \& Amorim CA 2014 A new step toward the artificial ovary: survival and proliferation of isolated murine follicles after autologous transplantation in a fibrin scaffold. Fertility and Sterility 101 1149-1156. (https://doi. org/10.1016/j.fertnstert.2013.12.025)

Ma Y, Andrisse S, Chen Y, Childress S, Xue P, Wang Z, Jones D, Ko C, Divall S \& Wu S 2017 Androgen receptor in the ovary theca cells plays a critical role in androgen-induced reproductive dysfunction. Endocrinology 158 98-108. (https://doi.org/10.1210/en.2016-1608)

Matousek M, Carati C, Gannon B \& Brännström M 2001 Novel method for intrafollicular pressure measurements in the rat ovary: increased intrafollicular pressure after hCG stimulation. Reproduction 121 307-314. (https://doi.org/10.1530/rep.0.1210307)

McArthur ME, Irving-Rodgers HF, Byers S \& Rodgers RJ 2000 Identification and immunolocalization of decorin, versican, perlecan, nidogen, and chondroitin sulfate proteoglycans in bovine small-antral ovarian follicles. Biology of Reproduction 63 913-924. (https://doi.org/10.1095/ biolreprod63.3.913)

McIntush EW \& Smith MF 1998 Matrix metalloproteinases and tissue inhibitors of metalloproteinases in ovarian function. Reviews of Reproduction 3 23-30. (https://doi.org/10.1530/ror.0.0030023)

McKey J, Bunce C, Batchvarov IS, Ornitz DM \& Capel B 2019 Neural crest-derived neurons invade the ovary but not the testis during mouse gonad development. PNAS 116 5570-5575. (https://doi.org/10.1073/ pnas.1814930116)

Mescher AL 2018 Epithelial Tissue. New York, NY: McGraw-Hill Education.

Miyabayashi K, Tokunaga K, Otake H, Baba T, Shima Y \& Morohashi K 2015 Heterogeneity of ovarian theca and interstitial gland cells in mice. PLoS ONE 10 e0128352. (https://doi.org/10.1371/journal.pone.0128352)

Monniaux D, Huet-Calderwood C, Le Bellego F, Fabre S, Monget P \& Calderwood DA 2006 Integrins in the ovary. Seminars in Reproductive Medicine 24 251-261. (https://doi.org/10.1055/s-2006-948554)

Neilson D, Seegar Jones GS, Woodruff JD \& Goldberg B 1970 The innervation of the ovary. Obstetrical and Gynecological Survey 25 889-904. (https://doi.org/10.1097/00006254-197010000-00001)

Norman RJ \& Brannstrom M 1994 White cells and the ovary - incidental invaders or essential effectors? Journal of Endocrinology 140 333-336. (https://doi.org/10.1677/joe.0.1400333)

Okamura H, Takenaka A, Yajima Y \& Nishimura T 1980 Ovulatory changes in the wall at the apex of the human Graafian follicle. Journal of Reproduction and Fertility 58 153-155. (https://doi.org/10.1530/jrf.0.0580153)

Oksjoki S, Rahkonen O, Haarala M, Vuorio E \& Anttila L 2004 Differences in connective tissue gene expression between normally functioning, polycystic and post-menopausal ovaries. Molecular Human Reproduction 10 7-14. (https://doi.org/10.1093/molehr/gah003)

Ouni E, Vertommen D, Chiti MC, Dolmans MM \& Amorim CA 2019 A draft map of the human ovarian proteome for tissue engineering and clinical applications. Molecular and Cellular Proteomics 18 S159-S173. (https://doi.org/10.1074/mcp.RA117.000469) 
Pepe G, Locati M, Della Torre S, Mornata F, Cignarella A, Maggi A \& Vegeto E 2018 The estrogen-macrophage interplay in the homeostasis of the female reproductive tract. Human Reproduction Update $\mathbf{2 4}$ 652-672. (https://doi.org/10.1093/humupd/dmy026)

Rastetter RH, Bernard P, Palmer JS, Chassot AA, Chen H, Western PS, Ramsay RG, Chaboissier MC \& Wilhelm D 2014 Marker genes identify three somatic cell types in the fetal mouse ovary. Developmental Biology 394 242-252. (https://doi.org/10.1016/j.ydbio.2014.08.013)

Reeves G 1971 Specific stroma in the cortex and medulla of the ovary. Cell types and vascular supply in relation to follicular apparatus and ovulation. Obstetrics and Gynecology 37 832-844. (https://doi. org/10.1097/00006254-197203000-00016)

Rensen SSM, Doevendans PAFM \& van Eys GJJM 2007 Regulation and characteristics of vascular smooth muscle cell phenotypic diversity. Netherlands Heart Journal 10015 100-108. (https://doi.org/10.1007/ BF03085963)

Richards JS, Ren YA, Candelaria N, Adams JE \& Rajkovic A 2018 Ovarian follicular theca cell recruitment, differentiation, and impact on fertility: 2017 update. Endocrine Reviews 39 1-20. (https://doi.org/10.1210/ er.2017-00164)

Rios PD, Kniazeva E, Lee HC, Xiao S, Oakes RS, Saito E, Jeruss JS, Shikanov A, Woodruff TK \& Shea LD 2018 Retrievable hydrogels for ovarian follicle transplantation and oocyte collection. Biotechnology and Bioengineering 115 2075-2086. (https://doi.org/10.1002/bit.26721)

Rodgers RJ, Lavranos TC, van Wezel IL \& Irving-Rodgers HF 1999 Development of the ovarian follicular epithelium. Molecular and Cellular Endocrinology 151 171-179. (https://doi.org/10.1016/S03037207(99)00087-8)

Rolaki A, Drakakis P, Millingos S, Loutradis D \& Makrigiannakis A 2005 Novel trends in follicular development, atresia and corpus luteum regression: a role for apoptosis. Reproductive Biomedicine Online 11 93-103. (https://doi.org/10.1016/s1472-6483(10)61304-1)

Rotgers E, Jørgensen A \& Yao HH-C 2018 At the crossroads of fate somatic cell lineage specification in the fetal gonad. Endocrine Reviews 39 739-759. (https://doi.org/10.1210/er.2018-00010)

Rotterdam ESHRE/ASRM-Sponsored PCOS Consensus Workshop Group 2004 Revised 2003 consensus on diagnostic criteria and long-term health risks related to polycystic ovary syndrome (PCOS). Human Reproduction 19 41-47. (https://doi.org/10.1093/humrep/deh098)

Rowley JE, Amargant F, Zhou LT, Galligos A, Simon LE, Pritchard MT \& Duncan FE 2020 Low molecular weight hyaluronan induces an inflammatory response in ovarian stromal cells and impairs gamete development in vitro. International Journal of Molecular Sciences 21 1036. (https://doi.org/10.3390/ijms21031036)

Russo L, Woolmough E \& Heatley MK 2000 Structural and cell surface antigen expression in the rete ovarii and epoophoron differs from that in the Fallopian tube and in endometriosis. Histopathology 37 64-69. (https://doi.org/10.1046/j.1365-2559.2000.00938.x)

Salvetti NR, Gimeno EJ, Canal AM, Lorente JA \& Ortega HH 2003 Histochemical study of the extracellular matrix components in the follicular wall of induced polycystic ovaries. Brazilian Journal of Morphological Sciences 20 93-100.

Schmidt J, Weijdegård B, Mikkelsen AL, Lindenberg S, Nilsson L \& Brännström M 2014 Differential expression of inflammation-related genes in the ovarian stroma and granulosa cells of PCOS women. Molecular Human Reproduction 20 49-58. (https://doi.org/10.1093/ molehr/gat051)

Scott JE, Carlsson IB, Bavister BD \& Hovatta O 2004 Human ovarian tissue cultures: extracellular matrix composition, coating density and tissue dimensions. Reproductive Biomedicine Online 9 287-293. (https://doi. org/10.1016/s1472-6483(10)62143-8)

Siu MKY \& Cheng CY 2012 The blood-follicle barrier BFB in disease and in ovarian function. Advances in Experimental Medicine and Biology $\mathbf{7 6 3}$ 186-192. (https://doi.org/10.1007/978-1-4614-4711-5_9)

Smith RM, Shikanov A, Kniazeva E, Ramadurai D, Woodruff TK \& Shea LD 2014 Fibrin-mediated delivery of an ovarian follicle pool in a mouse model of infertility. Tissue Engineering: Part A 20 3021-3030. (https:// doi.org/10.1089/ten.TEA.2013.0675)

Soares M, Sahrari K, Chiti MC, Amorim CA, Ambroise J, Donnez J \& Dolmans MM 2015 The best source of isolated stromal cells for the artificial ovary: medulla or cortex, cryopreserved or fresh? Human Reproduction 30 1589-1598. (https://doi.org/10.1093/humrep/dev101)
Spinder T, Spijkstra JJ, van den Tweel JG, Burger CW, van Kessel H, Hompes PGA \& Gooren LJG 1989 The effects of long term testosterone administration on pulsatile luteinizing hormone secretion and on ovarian histology in eugonadal female to male transsexual subjects. Journal of Clinical Endocrinology and Metabolism 69 151-157. (https:// doi.org/10.1210/jcem-69-1-151)

Stévant I, Kühne F, Greenfield A, Chaboissier MC, Dermitzakis ET \& Nef S 2019 Dissecting cell lineage specification and sex fate determination in gonadal somatic cells using single-cell transcriptomics. Cell Reports $\mathbf{2 6}$ 3272.e3-3283.e3. (https://doi.org/10.1016/j.celrep.2019.02.069)

Suzuki T, Sasano H, Takaya R, Fukaya T, Yajima A, Date F \& Nagura H 1998 Leukocytes in normal-cycling human ovaries: immunohistochemical distribution and characterization. Human Reproduction 13 2186-2191. (https://doi.org/10.1093/humrep/13.8.2186)

Svingen T, François M, Wilhelm D \& Koopman P 2012 Three-dimensional imaging of Prox1-EGFP transgenic mouse gonads reveals divergent modes of lymphangiogenesis in the testis and ovary. PLOS ONE 7 e52620. (https://doi.org/10.1371/journal.pone.0052620)

Taipale J \& Keski-Oja J 1997 Growth factors in the extracellular matrix. FASEB Journal 11 51-59. (https://doi.org/10.1096/fasebj.11.1.9034166)

Takamoto N, Kurihara I, Lee K, DeMayo FJ, Tsai MJ \& Tsai SY 2005 Haploinsufficiency of chicken ovalbumin upstream promoter transcription factor II in female reproduction. Molecular Endocrinology 19 2299-2308. (https://doi.org/10.1210/me.2005-0019)

Theocharis AD, Skandalis SS, Gialeli C \& Karamanos NK 2016 Extracellular matrix structure. Advanced Drug Delivery Reviews 97 4-27. (https://doi. org/10.1016/j.addr.2015.11.001)

Tian Y, Shen W, Lai Z, Shi L, Yang S, Ding T, Wang S \& Luo A 2015 Isolation and identification of ovarian theca-interstitial cells and granulose cells of immature female mice. Cell Biology International 39 584-590. (https:// doi.org/10.1002/cbin.10426)

Tingen CM, Kiesewetter SE, Jozefik J, Thomas C, Tagler D, Shea L \& Woodruff TK 2011 A macrophage and theca cell-enriched stromal cell population influences growth and survival of immature murine follicles in vitro. Reproduction 141 809-820. (https://doi.org/10.1530/REP-10-0483)

Turner EC, Hughes J, Wilson H, Clay M, Mylonas KJ, Kipari T, Duncan WC \& Fraser HM 2011 Conditional ablation of macrophages disrupts ovarian vasculature. Reproduction 141 821-831. (https://doi.org/10.1530/REP10-0327)

Uchida S 2015 Sympathetic regulation of estradiol secretion from the ovary. Autonomic Neuroscience: Basic and Clinical 187 27-35. (https:// doi.org/10.1016/j.autneu.2014.10.023)

Wagner M, Yoshihara M, Douagi I, Damdimopoulos A, Panula S, Petropoulos S, Lu H, Pettersson K, Palm K, Katayama S et al. 2020 Singlecell analysis of human ovarian cortex identifies distinct cell populations but no oogonial stem cells. Nature Communications 11 1147. (https:// doi.org/10.1038/s41467-020-14936-3)

Wang S, Zheng Y, Li J, Yu Y, Zhang W, Song M, Liu Z, Min Z, Hu H, Jing Y et al. 2020 Single-cell transcriptomic atlas of primate ovarian. Aging Cell 180 585-600.e19. (https://doi.org/10.1016/j.cell.2020.01.009)

Wenzel JGW \& Odend'hal S 1985 The mammalian rete ovarii: a literature review. Cornell Veterinarian 75 411-425.

West ER, Xu M, Woodruff TK \& Shea LD 2007 Physical properties of alginate hydrogels and their effects on in vitro follicle development. Biomaterials 28 4439-4448. (https://doi.org/10.1016/j.biomaterials.2007.07.001)

West-Farrell ER, Xu M, Gomberg MA, Chow YH, Woodruff TK \& Shea LD 2009 The mouse follicle microenvironment regulates antrum formation and steroid production: alterations in gene expression profiles. Biology of Reproduction 80 432-439. (https://doi.org/10.1095/ biolreprod.108.071142)

Wu R, Van der Hoek KH, Ryan NK, Norman RJ \& Robker RL 2004 Macrophage contributions to ovarian function. Human Reproduction Update 10 119-133. (https://doi.org/10.1093/humupd/dmh011)

Wu R, Fujii S, Ryan NK, Van der Hoek KH, Jasper MJ, Sini I, Robertson SA, Robker RL \& Norman RJ 2007 Ovarian leukocyte distribution and cytokine/chemokine mRNA expression in follicular fluid cells in women with polycystic ovary syndrome. Human Reproduction 22 527-535. (https://doi.org/10.1093/humrep/del371)

Wu C, Xu B, Li X, Ma W, Zhang P, Chen X \& Wu J 2017 Tracing and characterizing the development of transplanted female germline stem cells in vivo. Molecular Therapy 25 1408-1419. (https://doi. org/10.1016/j.ymthe.2017.04.019) 
Xu J, Zheng T, Hong W, Ye H, Hu C \& Zheng Y 2018 Mechanism for the decision of ovarian surface epithelial stem cells to undergo neo-oogenesis or ovarian tumorigenesis. Cellular Physiology and Biochemistry 50 214-232. (https://doi.org/10.1159/000494001)

Young JM \& McNeilly AS 2010 Theca: the forgotten cell of the ovarian follicle. Reproduction 140 489-504. (https://doi.org/10.1530/REP-10-0094)

Young B, O'Dowd G \& Woodford P 2014 Cell Structure and Function. Philadephia: Churchill Livingstone.

Younis JS, Jadaon JE, Haddad S, Izhaki I \& Ben-Ami M 2011 Prospective evaluation of basal stromal Doppler studies in women with good ovarian reserve and infertility undergoing in vitro fertilization-embryo transfer treatment: patients with polycystic ovary syndrome versus ovulatory patients. Fertility and Sterility 95 1754-1758. (https://doi.org/10.1016/j. fertnstert.2011.01.007)

Zarate-Garcia L, Lane SIR, Merriman JA \& Jones KT 2016 FACS-sorted putative oogonial stem cells from the ovary are neither DDX4-positive nor germ cells. Scientific Reports 6 27991. (https://doi.org/10.1038/ srep27991)

Zhang H, Zheng W, Shen Y, Adhikari D, Ueno H \& Liu K 2012 Experimental evidence showing that no mitotically active female germline progenitors exist in postnatal mouse ovaries. PNAS 109 12580-12585. (https://doi. org/10.1073/pnas.1206600109)

Zhang Y, Yan Z, Qin Q, Nisenblat V, Chang HM, Yu Y, Wang T, Lu C, Yang M, Yang S et al. 2018 Transcriptome landscape of human folliculogenesis reveals oocyte and granulosa cell interactions. Molecular Cell 721021 1034.e4. (https://doi.org/10.1016/j.molcel.2018.10.029)

Zhang Z, Schlamp F, Huang L, Clark H \& Brayboy L 2020 Inflammaging is associated with shifted macrophage ontogeny and polarization in the aging mouse ovary. Reproduction 159 325-337. (https://doi. org/10.1530/REP-19-0330)

Received 21 October 2019

First decision 22 November 2019

Revised manuscript received 18 June 2020

Accepted 23 June 2020 